\title{
Map of Da'wah: Religious Polarization and Affirmation of Identity of Islamic Societies In Lombok, Indonesia
}

\section{Fahrurrozi*, Muhammad Thohri \\ UIN Mataram}

Jl. Gajah Mada No. 100, Kota Mataram, Nusa Tenggara Barat. 83116

\begin{tabular}{l|l|l} 
Submitted: $21^{\text {th }}$ April 2020 & Revised: $2^{\text {nd }}$ May 2020 & Accepted: $10^{\text {th }}$ July 2020
\end{tabular}

\begin{abstract}
This study's finding is religious polarization confirming the Identity of Lombok Islamic Societies emerging since before Indonesia's independence by taking the religious movement form. Mainstream religious movement in Lombok is Sunni one and not all of them are under organizational flag, but generally based on educational institution. Minority non-sunni movement brought an effect and wahabi movement pattern emphasizing on "the differentiation" of religious practice, so that it is not ideological wrestling but identity contestation that occurs. Then, religiosity identity of Lombok Islamic societies is material-symbolic and accommodative in nature. The accommodative religious practice occurs in tasawwuf practices and encounters acculturation as the identity of Lombok Muslim. Islamic religious Identity in Lombok Sunni has been existing long before the development of religious organization and educational institution, so that the Sasak Islamic Identity encountered acculturation as the result of natural construction of Lombok Islamic societies. Organizational diversity, movement, and identity solidification can be a wealth as long as it is not debated in the public space.
\end{abstract}

Keywords: Sasak Identity, solidification, Tuan Guru, Islamic Organization, Dakwah

\section{INTRODUCTION}

These diverse understandings, creeds, organization, and elements occurring amid Sasak Muslim in Lombok have not been categorized into a comprehensive study because it has not been mapped well and clearly between on element and another. It has not been identified clearly why People with ahlussunnah wal jamaah movement polarize and are affiliated with ahlussunnah wal jamaah; similarly, the societies formerly adhered to cultural and Islamic tenet tightly switch totally to Islam fundamentalism unwilling to interact with local culture. It is these phenomena that create 
religious polarization requiring a study to be conducted in the Map of Da'wah form.

A variety of religious perspectives and practices developing in Sasak community currently makes less disharmonious friction within Sasak community. This friction or even gap likely affects broadly the society's religious behavior that can ignite the conflict fire on behalf of religion. This point is important to investigate the map of da'wah that can lead to network and stream becoming the mapping problem to the recent reality of da'wah.

It is interesting to investigate the very diverse religious polarization of Lombok Sasak community. Recently, the polarization is getting more prominent compared with one or two last decades. Religious polarization in the beginning eras is vague, as it is limited to the hidden schools of thought due to the strong hegemony of religious and community leaders at that time. Sasak Islam in early decades may be said as having Ahlussunnah wal Jamaah or traditionalist-accommodative perspective interacting with local wisdom culture and tradition, however since reform in 1998, some religiosity patterns emerge within Sasak community that are uncommon culturally (Wacana, 1979). Similarly, the identity of Sasak community is known as "lombo" (straightforward) community, "jama'-jama'" (elegant, ordinary, not vulgar) community or Sasak community "with Islam" (Islam people). This reform era impacts on the change and biased identity of indigenous Sasak community (al-Hakim, 2012).

One of Lombok's uniqueness with a variety of Island, the majority population of which is Muslim in Indonesia is the existence of many masjid (mosque) buildings. It can be nearly ensured that each kampung (village) has mosque. Those masjids are large and luxurious. It is unsurprising that some people said that santren (read; mushalla) in Lombok Island, has been considered as mosque (masjid) in Javanese Island. Interestingly, despite luxury, the masjids (mosques) in Lombok are constructed - with any exception - rarely through begging on the street just like what occurs in some places. Begging is considered as an action that can embarrass the village. The spirit shows high religious consciousness level of Lombok community.

The religiosity of sasak tribe community as indigenous dwellers of Lombok Island to establish masjid makes this Island called a thousandmosque Island, just like Bali called A thousand-temple island. Even masjid originally serving as a place for Muslim to do sholat and pray, shift into a kind of social prestige to each of villages (kampong). For example, certain village will see other village shyly if it has no its own masjid (Arzaqi, 
2001). In Islam religion, masjid occupies the very strategic position for Islam development and community empowerment. During Prophet Muhammad time, masjid functioned not only as place for worship but also administrative center, dakwah center, and headquarter to design strategy to fight against aggressor. Masjid in Islam early time had multifunction, in addition to function do shalat (Judd, 2016).

The position of religion is very important to Sasak community's consciousness in Lombok Island. Religion serves not only social foundation in building individual and group morality, but moves and integrates into cultural system. Although Sasak community in Lombok does not have verbal principle like Minang tribal community, adat bersandi syara', syara' bersandi kitabullah, to Lombok community, religion should support all lines of social, cultural, and political systems. Therefore, breaking religious law is something intolerable as it is often considered as breaking the tradition (Asnawi, 2006). Simply, traditional identity refers to ethnicity, group, or collective function. Meanwhile, identity modernity is individual character developing uniquely to create certain individuality function (Kellner, 1995).

Some actions taken by Lombok Sasak community against the existence of Ahmadiyah group forcing its adherents to move from their village is a small part of the example. Or anarchic treatment in Lombok Barat by throwing stone and expelling Salafy movement's adherents from the village should be observed as well. Negative stigma is also encountered by Muhammadiyah organization group in their early time of growing their organization in this a-thousand-mosque Island. The existence of movements different from ancestor religiosity practice is not only considered as deviating, but also is taken account as a threat. Therefore, repressive aggression is conducted as excessive defensive attitude to local community's feeling of being threatened related to their hereditary creed. The centrum of Social Structure in feudal society is priyayi (upper class) occupying the top position, because it becomes not only a leader in the world but also the representation of gods' reincarnation in the sky. Social structure changes when societal system changes from traditional-based to religious-based. The role of priyayi is taken over by religious leaders. The king no longer holds double controls (religion and state) but plays function in the state domain only (despite non determinant). The religious area only becomes the kiai's authority. Such the description also occurs in Sasak community. The feudal track now moves to the charismas of Tuan Guru (Islamic Scholar in Java). Tuan Guru becomes one of charismatic centrum within Sasak society (Jamaluddin, 2010). 
Considering this, it is the time for the society to manipulate symbol, and from the symbol the society is defeated and no longer sees the reality or in other words "the content of message of being defeated by the message packager". When a society has been "infected" with symbol, simulacrum will start to stick into its life. In Baudrillard's definition, this simulacrum is a construction of imaginary thought on a reality, without presenting the reality itself essentially; in other words, simulacrum is an instrument that can change the abstract matters into the concrete ones and the concrete into the abstract ones (Baudrillard, 1998).

Global time like nowadays gives a sufficiently significant opportunity for social-horizontal mobility to occur cross-island and even crosscontinent. Space barely becomes constraint and for that reason, state borders are almost obscure, although the term "Sasak" above emphasizes more one ethnical nuance, the factor of commitment to what is called "Sasak culture and primordialism" still needs consideration. So, Sasak society intended here is the one Sasak ethnic community still committed to its culture and having strong primordialism bond spirit (Allan.G, 1995).

It can be ensured nearly that when the society shifts to religion-based, religion leader occupies the top position. In addition to in Lombok, it can also be seen in Maduranese society. Kiai (teacher of Islam)'s say is as if an unquestionable command. It is in contrast to Java, in which tradition basis is still stronger than religion basis, e.g. Yogyakarta and Solo, where courts (palaces) still become the center (centrum) (Steenbrink, 1984). Therefore, we rarely find Javanese people so fanatical to their kiai, but in coastal Java area exactly in North Beach. Tuan Guru, in Lombok society, is one of very respected and exalted positions.

Therefore, religion plays a considerable role within Lombok society. The social changes can be made if religion is put on urgent role in the social reengineering agenda in Lombok society. The central position such as tuan guru, masjid, and etc should be engaged. Sasak people's fanaticism with religion is a social asset that should be maintained continuously amid foreign tradition's invasion filling in our social-cultural spaces, on the one hand. However, on the other hand, if it is managed incorrectly, it will likely threaten democratization and advance in Lombok. For example, a tragedy will likely explode later, exceeding the racism riot occurring in 2000 or discrimination against Ahmadiyah adherents (Fahrurrozi, 2015) 


\section{RESULT AND DISCUSSION \\ Religious Polarization in Lombok}

Islam community polarization in some groups can be triggered by geographic, ideological, cultural, economic, and political factors. Geographically, West Asian region has pattern different from Muslim community in Middle Asia and South East Asia. Lombok Muslims can also be seen from geographic aspect, despite no contrasting difference in which southern area of Lombok is a relatively dry one with warmer temperature and religious characteristics different from those residing in fertile land in thee north, exactly in the slope of mount Rinjani with low temperature, despite equally agrarian communities (Interview; Abidin, 2018).

Religious polarization in Lombok can be seen from geographical oriented identity: rural and urban Muslim communities. Rural communities are identical with those with income from agrarian sector, while urban community from non-agrarian sector. Administratively, rural communities reside rural area and urban ones reside urban areas (Azra, 1985). Ideologically, the geographic-based polarization is often identical with two groups: intellectual and lay groups. The lay group is the form of rural community's claim, while intellect group is the form of urban community's claim. Naming and predicate in family domain can be distinguisher such as inak-amak, papu-balok, and etc constituting the signifier of polarization. The intellectual-lay classification seems to be introduced by means of way of thinking (mindset) rather than ideological matter. But, somehow this claim is the form of identification confirming the identity (Interview; Hadi, 2018).

Ideologically, polarization also results from the way of thinking or perception on religion and societal problem. Some groups have rigid perception on the meaning of text, including religious manuscript or narration. Some other groups are more accommodative by seeing social problems and putting culture as something appreciated for its existence (what it is). Ideological-based polarization also arises considering the function of science (knowledge) and mind in understanding the religious textual narration and social problem. So there are three factors causing polarization in ideological aspects: rationalistic, fundamentalistic, and accommodationist. These three thinking models have different orientation with their own strengths and weaknesses (Interview; Munir, 2018).

Religion-based society organizations, shown by NU, NW, and Muhammadiyah, have binding power in a community. These three organizations not only accentuate identity but also put obedience to be 
the basis of members' bond and consciousness. There is dogmatic aspect taught as the part of organizational identity. Therefore, organization has an authority to create conviction and obedience to organization. In this context, there is a kind of communal ideology defended (Interview; alIdrus, 2018).

Trio-Sunni in Lombok confirms the organizations caring about not only religiosity awareness but also humanity development. Trio-sunni in Lombok also confirms the real contribution to the reinforcement of nationality aspect. In its history, trio-sunni has indeed become the activator of independence struggle movement in Indonesia. Founders and administrators of Islamic organization with dominant influence were Islam activists and nationalists all at once. Activists of NU, NW, and MU, as well as other organizations have put hubbul wathan to be a part of their doctrine. See Hizbul Wathan Muhammadiyah's scouting, NU Ahlal Wathan song by NU's founders and NWDI's marching tune by NW's founders. Some Islam movement organizations in Lombok operate through political channel like SI and NU, Perti, and PSII, and Parmusi parties. All of these Islam parties have good relation to Nahdlatul Wathan Islam organization, particularly during 1950-1960.

\section{Religious Identity \\ Material Identity}

Tuan Guru suit Religious identity can be seen from the proselytizing actor's suit (clothes), particularly Tuan Guru's and the difference of dressing pattern. Their dressing pattern also becomes the religious identity of Lombok society. All Tuan Gurus have ever done pilgrimage. If they teach religion or become lecturers (the ones giving lecturer), they called ustadzs. Ustadz is characterized with black songkok (rimless cap), and Tuan Guru with white songkok.

Viewed from zoning aspect, Tuan Guru's dressing patterns are different in East and West areas of Lombok. Tuan Guru in East Lombok area usually wear top (pakaian kurung or sack dress). They also wear turban (imamah), i.e. the cloth twisted on the head. It is different from Tuan Guru in West Lombok area with simple clothing, using coat plus white songkok only. Some others also wear top and white songkok without turban. In middle area, Tuan Guru tends to follow the dressing pattern of East Lombok, particularly Tuan Guru based on Nahdlatul Wathan and Madrasah al-Shaulatiyah Makkah alumni (Fahrurrozi, 2018).

Religious identity is affected much more by social interaction process. Tuan gurus of NW in middle and east areas have intense interaction with each other, thereby creating communal identity. In West Lombok area 
and Mataram city, relatively opened interaction occurs with many classes of society making the dressing mode of Tuan Guru simpler in this region. Tuan gurus of NU are also simpler in dressing mode. Meanwhile, Tuan gurus of Muhammadiyah do not accentuate their pilgrimage (ke-haji-an) to be accepted as $d a^{\prime} I$ or Tuan Guru in Muhammadiyah.

Turban and baju kurung (top) are generally worn by tuan gurus of Nahdlatul Wathan and members of tabligh congregation group. Wearing turban but not wearing baju kurung is the characteristic of tuan guru with multi-classes mass or in certain event. Tuan gurus of NU are looser in the term of dressing. Wearing white songkok with turban worn diagonally over body also characterize Tuan Gurus in West Lombok area, although not all of them do so.

White songkok is also used varyingly. The adherents of Wahabi Salafi tenet and tabligh congregation community generally wear round hajj cap (songkok), tuan gurus of NW and NU usually wear national-pattern hajj cap. National cap (songkok) is worn by tuan gurus, da'i and ustadz in urban areas. Group or organization familiar with this songkok includes ustaz (non-tuan guru) from NW, NU, and kiai Muhammadiyah. Religious leader in sunni organizations are generally familiar with songkok as religious identity. Meanwhile PKS group is unfamiliar with songkok, either white or national (Interview; Khairi, 2018).

Non-sunniy harakah da'wah groups are usually characterized with the way of wearing underwear. Members of Non-sunniy harakah da'wah group generally holds on hadits isbal, the improperness of wearing clothes touching the heel. They generally using shorter trousers, usually without head cover. It is also a factor distinguishing them from others (Interview; Khairi, 2018).

Muslimah's dressing mode also becomes religious identity. Sunniy communities are commonly dressing simply with the principle of covering aurat. After salafiy wahabiy school of thought enters into school and college, Muslimahs wearing burka (veil) emerge. It becomes identity inherent to certain community and leads to the diversity of religiosity identity. Such way of dressing is not existent in Indonesian culture. It is just like national songkok that is not Islamic songkok but has been Indonesian and even South East Asian Muslims' identity. Therefore, culture affects religious identity. The use of burka (veil) actually preserves other region's culture, particularly West Asian region's culture. That is a group's social-religious identity.

Santri Suit. Suit (clothing) is also an attribute of religious identity. Baju koko is presupposed to be Chinese' ethnic clothes accepted widely by Muslims and even acquired to be Muslim clothes. Baju koko model with 
opened long sleeves and upright collar become South East Asian Muslims' identity. Baju koko is worn by Muslim students in both pesantren (Islamic Boarding School) and non-pesantren. Similarly, koko is also worn by children and ustadzs in special events.

Santri muslim is also identical with head cover called kopiah or songkok. There are two types of Songkok worn: cloth- and velvet-based songkoks. Velvet-based songkok is usually black and identical with national songkok. In formal education hour, Islamic school wears national songkok particularly in NU and NW schools. Additionally, they also wear roundshaped cloth songkok with not too varying colors. It is usually white songkok only. In some Islamic schools such as Muhammadiyah schools, they wear neither white nor black songkok. Wahaby Salafy school does not wear songkok. Head cover as if becomes santri muslim's identity in Lombok, except in Muhammadiyah institution. The similarity between Sunni and formal schools lies on no Arab-fashion model worn.

Sarung is also santri identity and religious identity, although, in fact, sarung is South Asian clothes rather than West Asian (Arab) clothes. Nahdhiyyin Santris are familiar with sarung in both inside and outside school environment. Meanwhile, non-Nahdiyyin santris are not required to wear sarung. Non-Nadhiyyin santri children wear sarung on Sholat Jumat or certain event only. Non-Nahdhiyyin santris are trained to wear trousers and unfamiliar with cloth. Wahaby Salafy santris are taught to wear trousers not touching the heel. Nahdhiyyin and Muhammadiyah wear usual trousers. Wahaby Salafy wears three-fourth size trousers.

Muslimah santris obligatorily wear headgear (jilbab) and of course wear clothes covering aurat. Jilbab is a term for cloth covering santri's head. All female (muslimah) santris in Lombok wear jilbab as Muslimah identity. Meanwhile, only female santris in Salafy Islamic boarding schools (pondok) wear veil (burka) and veil is not popular among ordinary people. Female santris Pondok Abu Hurairah Mataram and Pondok As-Sunnah Bagek Nyaka wear veil (burka).

Beard and Forehead This group holding on zahir-nash is still growing beard as its identity. Beard becomes their group's identity. To NU scholars (ulama NU), Muhammadiyah, and NW, beard is sunnah rather than identity emphasized on within community. Meanwhile, for wahabi, salafi, tabligh community and PKS members, beard is an identity. These groups' identity can also include the blackened forehead. It is based on the implementation of zahir nash meaning. Santri children holding on this thought usually rub their forehead to get the black sign on their forehead. Non-sunni community members use forehead blackening as their identity. The significant role of figh in the acculturation of Islam tenets 
into a tradition in local culture can be seen in figh development among Sasak people in Lombok known for their obedience to their religion tenet and local tradition all at once. Among Sasak people, figh and culture are two inseparable matters. Figh underlies the culture, and otherwise, culture colors the figh itself.

Flag/Symbol Islam organization has symbol as an identity. An exception applies to the movement having no specific flag or symbol as the sign of identity. Symbol of Islam organization is star. Nahdlatul Ulama uses star, so do Muhammadiyah and Nahdlatul Wathan. Similarly, NW uses star along with crescent moon. NW star has five beams and transmits five rays. NU uses nine five-beam stars with the picture of globe and rope node. Muhammadiyah uses an eight-beam star, on which the word "Muhammadiyah" is written in Arabic. Nahdlatul Wathan uses an eight-beam star for its madrasah, Madrasah Nahdlatul Wathan Diniyah Islamiyah (NWDI).

Religiosity group not bond by organization usually has no flag or symbol registered officially to the state. Symbol or logo is used by them for school or education institution purpose only. There is a difference of logo between school and organization. Arabic letters are used on NU and Muhammadiyah flags, while Latin on NW flag. The choice of Latin rather than Arabic letters was made by its founder.

Identity as a key element of subjective reality and just like subjective reality is related dialectically to the society, so that identity is created by social processes (Berger, 1990). Viewed from constructivism, the acceptability of religious identity to religious organization changes related to its ownership along with its context. So does istighasah in NU. Istighasah identical with NU's property has been acceptable to public as religious practice that is opened in nature. Istighasah is no longer conducted exclusively by NU community members. In religious activity cases initiated by Local Government or certain groups beyond NU, istighasah has been acceptable to NW community members themselves. Istighasah that is incidental in nature is not as same as hiziban activity schedule every Thursday night or Tuesday night to jama'ah thariqat. Hiziban is used more evenly due to the availability of hizib reading book obtained easily.

Religious identity, in principle, can be seen from exclusivism or inclusivism in understanding religion, or fundamentalism represented by salafiy-wahabiy, HTI, and PKS, and radicalism represented by FPI and MMI. For radicalism case, the identity is not so popular that it is identified difficultly. Religious identity often becomes identity politics by utilizing religious sentiment issue as its commodity and self and group 
confirmation as Islam defender. Therefore, such group has group identity built assumptively and trusted by the society. Group and group identity are two inseparable matters. Both are a uniting entity. The more contrasting the difference of identity, the easier are the identification, the recognition, and the remembrance of it. Lombok also displays a variety of identities: group, class, and organization.

Plurality is a certainty. Lombok also faces religion, ethnic, language, and religion perspective plurality. Lombok cultures are also plural, affected by custom, belief, or other influences. Lombok has most unique culture, recalling that this Island is located in east and west intersection. Majority populations of eastern area are Christian, while those of western area are Hindu. In this context, the authors take a stance of reading identity by multicultural approach.

Multiculturalism as living culture surely encounters some frictions between groups or classes. Social-religious group surely shows off contestation spirit in the sense of competing or contesting. The contestation occurring is more cultural in nature as the result of social interaction. Such contestation often surfaces as the distinguisher in the sense of plurality rather than uniformity. Contestation of creed (belief) can be observed from cultural contestation.

Cultural contestation results in identity contestation. The competition among organizations, student groups, tuan gurus, pesantren (Islamic Boarding Schools), and even political dispute are the contestation of identity. Contestation of identity arises due to a desire to put the difference forward by means of making the differences colliding. The difference adapted without compromise is an attempt of differentiating increasing disparity between group and class. Sunni communities are represented by NW, NU, and Muhammadiyah have understood their own difference, particularly the difference between fellow Sunni communities. Meanwhile, non-Sunni groups, such as Wahabi, accentuate the difference.

Ways of dressing and praying, and declination against tenet are the accentuation of identity as a distinguishing attempt. The differentiation leads to what should be, while the difference in multicultural understanding is what it is. The attempt of accentuating the difference is an attempt of declining other communities' identity, particularly religious practice. Sunni group generally accepts difference more openly and tends to accept "difference". In many cases, tahlilan and yasinan formerly becomes a group's religious practice are now accepted just the way they are. Most of them are accepted without rationality and put suprarationality forward. 
Hiziban as the identity of Nahdlatul Wathan has been acceptable to Sasak society with diverse organizational background. The groups affiliated with NU organizations accept hiziban activity with an excuse of reading completeness and sing, and majority current loving hiziban. The motives can be just following others, need, and consideration as the citizens of region. So, it results in the acceptance of other groups' identity as a consensus just like. Istighosah as NU's identity is acceptable to NW community members and other citizens generally.

The contestation of identity confirms the occurrence of polarization so that one and another find more spaces. Interestingly, in Muhammadiyah's doctrine, Fastabikul Khairot becomes the content of doctrine; it is in line with NW's spirituality tenet called Basic Science, the reading source of which is also Fastabikul Khoirot. These two organizations encourage the health competition. NW and NU has shared platform in mobilizing their members to love doing sunnah worship in congregation. It is a worship (ibadah) and syiar all at once. Accentuating syiar is the form of identity publication and another form of healthy identity contestation. Identity contestation can create new polarization affected by perspective and understanding on religious practice. Wahabi group's perspective is different from sunni group's.

\section{CONCLUSION}

Identity diversity can be wealth as long as it is not contested in public space. Diversity is just like school uniform, in which color is not the principle, because its substance is dressing in the term of mapping the identity; it means to map the difference by identifying the difference of identity. This study also finds the shifting dynamic and the identity maintenance due to the friction of cultures. Polarization also occurs not only due to social problem or condition. But it occurs or is presents as creativity for confirming a group or an organization's identity only. Meanwhile, polarization is also present due to self and group actualization. The discourse limited to group attribute can be the confirmatory factor of polarization. As the form of grouping, polarization is the difference of identity and or that of understanding (perception). The first is sociological and the second is ideological problems.

Organization and movement diversities and identity confirmation can be a wealth as long as they are not contested in public space. Diversity is just like school uniform, in which color is not the principle, because its substance is dressing in the term of mapping the identity; it means to map the difference by identifying the difference of identity. This study 
also sees the shifting dynamic and the non-substantial identity maintenance, particularly among textualism adorers.

\section{REFERENCES}

Abdul, H. N. dan Sahafari, A. (1988). Nahdlatul Wathan: Organisasi Pendidikan, Sosial, dan Dakwah. Lombok: Toko Buku Kita.

Ahyar dan Acim, S. A. (2011). The Nyair Tradition of Kifayat al-Muhtaj As a Medium of Propagating Islam in Lombok, dalam Jurnal Penelitian Islam. 7. (2)

al-Hakim, L. (2012). Religiusitas Masyarakat Sasak, Mataram: LEPPIM IAIN Mataram.

Ariadi, L. M. (2017). Islam Sasak: Sebuah Manifestasi Fikih-Budaya, Jurnal Schemata Jurnal Pascasarjana UIN Mataram. 6 (2)

Asnawi. (2006). Agama dan Paradigma Sosial: Menyingkap Pemahaman Masyarakat Sasak Tentang TaqdirAllah Dan Kematian Bayi. Jakarta: Sentra Media. cet. 1.

Azra, A. (1985). Interaksi Agama dan Kebudayaandalam pengantar,Fachry Ali, Agama, Islam, dan Pembangunan. Yogyakarta: PLP2M.

Azra, A. (2007). Jaringan Ulama Timur Tengah dan Kepulauan Nusantara Abad ke XVII \& XVIII, (Bandung: Mizan, 1994).Cet. 3.

Baharuddin, NW Dan Perubahan Sosial. Yogyakarta: Panteon Press.

Bartholomen, J. R. (1999). Alif Lam Mim: Reconciling Islam, Modernity and Tradition in an Indonesian Kampung.

Bartholomen, J. R. (2001). Alif Lam Mim: Kearifan Masyarakat Sasak. Yogyakarta: PT Tiara Wacana.

Baudrillard, J. (1998). Consumer Society Myths and Structures. London, Thousand Oaks, New Delhi: Sage Publication.

Berger, L. B. dan Lukman, T. (1990). Tafsir Sosial atas Kenyataan, Risalah Tentang Sosiologi Pengetahuan. Jakarta: LP3ES.

Bianca , J. S. (2007). Re-orienting Famale Spiritual Power In Islam: Narrating Conflict between Warriors, Witches and Militias in Lombok, Indonesia, Journal of Indonesia and The Malay World 40 (118): 249-71.

Brigitta, H. S. \& David D. (Eds), (2008.) Between Harmony and Discrimination:Negotiating Religious Identities within MajortyMinority Relationships in Bali and Lombok, Leiden: Brill, Boston.

Budiwanti, E. (2000) Islam Sasak, Wetu Telu versus Wetu Lima, Yogyakarta: LkiS.

Dahlan, F. (2004). Paradigma Dakwah Sosiologis untuk Keberagaman Islam Indonesia. Mataram: LEPPIM IAIN Mataram. 
Dahlan, F. (2005). Sejarah Perjuangan dan Pergerakan Dakwah Islamiyah Tuan Guru Haji Muhammad Mutawalli di Pulau Lombok: Pendekatan Kultural dan Sufistik dalam mengislamisasi Masyarakat Wetu Telu. Jakarta: Sentra Media.

Dahlan, F. (2015). Budaya Pesantren di Pulau Seribu Masjid, Lombok, STAIN Pemekasan, Jurnal Karsa, Jurnal Terakreditasi BAN-PT.

Dahlan, F. (2015). Ekspresi Keberagamaan Masyarakat Islam Indonesia:Mozaik Multikulturalisme Indonesia, Jurnal TOLERANSI: Media Komunikasi Umat Beragama. 7 (1)

Dahlan, F. (2016). Tuan Guru: Eksistensi Peran dalam Transformasi Masyarakat. Jakarta: Sanabil Press.

Dahlan, F. (2017). Dakwah Akomodatif: Solusi Dakwah Aplikasi Fungsional pada Masyarakat Multikultural, Tasamuh, 15 (1)

Dahlan, F. (2017). Sosiologi Pesantren, Jakarta: Sanabil Press.

Djalaluddin, A. (2001). Nilai-Nilai Agama dan Kearifan Budaya Lokal. Mataram: Pokja Redam NTB.

Douglas, K. (1995). Media Culture: Cultural Studies, Identity And Politics Between Modern And Postmodern, London and New York: Routledge.

Geerzt, C. (2013). "Religion As a Cultural System"dalam Noorhaidi Hassan, The Making of Public Islam Piety, Democracy and Youth in Indonesian Politics. Yogyakarta: SUKA PRESS.

Ghazali, A. M. (2016). Islam Nusantara Dari Ushul Fiqh Hingga Paham Kebangsaan, cet. Ke-III. Bandung: PT Mizan Pustaka.

Jamaluddin, (2010). Sejarah Sosial Islam di Lombok 1740- 1933: Studi Kasus Terhadap Tuan Guru. Jakarta: Litbang Kemenag.

Johnson, A. G. (1995). The Blackwell Dictionary of Sociology: A User's Guide to Sociological Language, (Cambride: Blackwell Publisher Inc.

MaryPoo-Mooi, J. (2016). "The Sociology of Rural Povertyin Lombok Indonesia (Berkeley University: Ph.D thesis,1980) dalam Fawaizul Umam "Terma Pangkal Stigma" dalam Dari Bayan Untuk Indonesia Inklusif. Lombok: SOMASI NTB

Masnun, (2007). Tuan Guru KH Muhammad Zainuddin Abdul Madjid Gagasan dan Gerakan Pembaharuan Islam Di Nusa Tenggara Barat, Pustaka Al-Miqdad.

Mas'ud, A. (2006). Dari Haramain Ke Nusantara: Jejak Intelektual Arsitek Pesantren. Jakarta: Kencana Prenada Group. Cet. 1.

Mun'im, A. (2014). Islam Nusantara: Antara Harapan Prasangka dan Harapan yang Tersisa. Samarinda: AICIS Kementerian Agama RI Putrawan, A. (2017). Runtuhnya Karisma Tuan Guru. Mataram: Sanabil. 
Sahal, A. dan Aziz, M. (2016). Islam Nusantara dari Ushul Fiqh hingga Konsep Historis, Bandung: Mizan, Cet. III.

Steenbrink, K. A. (1984). Beberapa Aspek Islam di Indonesia Abad ke 19. Jakarta: Bulan Bintang.

Syakur, A. A. (2006). Islam dan kebudayaan Akulturasi Nilai-Nilai Islam Dalam Budaya Sasak. Yogyakarta, Fak Adab Press UIN Sunan Kalijaga.

Tylor, E. B. (1973). Primitive Culture, New York: Harper Toechbook.

Zuhdi, H. (2012). Praktik Merariq Wajah Sosial Masyarakat Sasak, Mataram: LEPPIM.

\section{Informants in Interview:}

Interview with Dr.TGH. Lalu Muhyi Abidin,MA, Secretary General of Nahdlatul Wathan's Managing Committee on July, 122018 in Mataram

Interview with Dr. Lalu Sirajul Hadi, M.Pd, an Academician, Cultural and Educational Activist, July 20, 2018 in Mujur, Lombok Tengah.

Interview with Dr. TGH. Zainal Arifin Munir, a Leader of Pondok Pesantren Munirul Arifin Praya on July 21, 2018 in Praya Lombok Tengah.

Interview with Prof. Dr.S.Aqil al-Idrus, M.Si, Nahdlatul Wathan's Managing Committee, Academician, Author, on August 28, 2018 in Mataram.

Interview with Nurcholis Muslim, Religious and Cultural Activist, July 22, 2018 in Dasan Tapen, Lombok Barat.

Interview with TGH. Muammar Arafat, a Leader of Pondok Pesantren Abhariyah and members of NTB Local Legislative Assembly (DPRD) on July 25, 2018 in Pagutan.

Interview with Dr.H.Kadri, Msi, Pakar Politik NTB and Chairperson of Policy Synchronizing Team of NTB Local Government, Mataram, August 12, 2018

Interview with Lalu Fauzi Hariyadi, an Educator and Observer of Lombok Culture, Mataram, August 27, 2018

Interview with M.Zainul Fahmi, cultural and educational activist, Mataram, August, 29, 2018.

Interview with Lalu Syafruddin, a lecturer of Unram, a Legal and Cultural Activist, Mataram, July 12, 2018

Interview with Lalu Mustajab, MA, a leader of Pondok Pesantren alIstiqomah Lingsar, on August 1, 2018 in Narmada Lombok Barat. 
Interview with TGH.Khairi, a leader of Pondok Pesantren TGH Sadaruddin NW Suralaga, an Academician and Religion Educator, Suralaga, on August 11, 2018.

Interviews in West Lombok in 2018 with H.Lutfi Arsyad, at the Religious Affairs Office, Lembar, August, 22.

Interview with H.Zakaria, MA, an Islam Religion Educator, Academician, and Religion Practitioner, Gunung Sari, Lombok Barat, August 20, 2018.

Interviews in West Lombok in 2018 with Nurkholis Muslim at Dasan Tapen, August 22.

Interview with TGH. Lalu Anas Hasry, a Leader of Pondok Pesantren Darul Abror NW Montong Kirik, Sakra Barat, Dewan Musytasyar PB NW, Rensing, August 13, 2018.

Interview with Dr. H. Nazar Naamy, Chairperson of NU's Subsidiary Office of Lombok Barat on August 12, 2018 in Dasan Geres Gerung Lombok Barat.

Interview with TGH. Hilmi Najamudin, a Leader of Pondok pesantren Raudhatuttholibin NW Montong Baan Sikur Lombok Timur, Dewan Musytasyar PB NW, Sikur, August 13, 2018.

Interview with H.Lalu Adnan Abu Bakar, Caretaker of Pondok Pesantren al-Amin Sepit Keruak, Administrator of NW Subsidiary Office of Keruak, on November 1, 2018 in Sepit Keruak, Lombok Timur.

Interview with TGH. Mukhlis Ibrahim, a leader of Pondok pesantren Ishlahuddiny Kediri Lombok Barat, Kediri, August 29, 2018.

Interview with Tuan Guru Bajang (TGB) KH.Lalu Gede Muhammad Zainuddin Atssani, Chairperson of NW's Regional Office of NTB, Rector of IAIH NW Lombok Timur NTB, Mataram, August 12, 2018 .

Interview with Dr. H. Abdurrahman Fajri, NW Managing Committee and Educational Activist, Mantang, August 19, 2018.

Interview with Dr. Faizah, MA, a Researcher on Salafi movement in Lombok, an academician of UIN Mataram, Mataram, August 11, 2018.

Interview with TGH. Muhammad Sholehuddin, Caretaker of Pondok Pesantren Syaikh ZainuddiJn NW Anjani, Former member of Local Legislative Assembly (DPRD) of Lombok Timur Regency, Anjani, August 20, 2018 